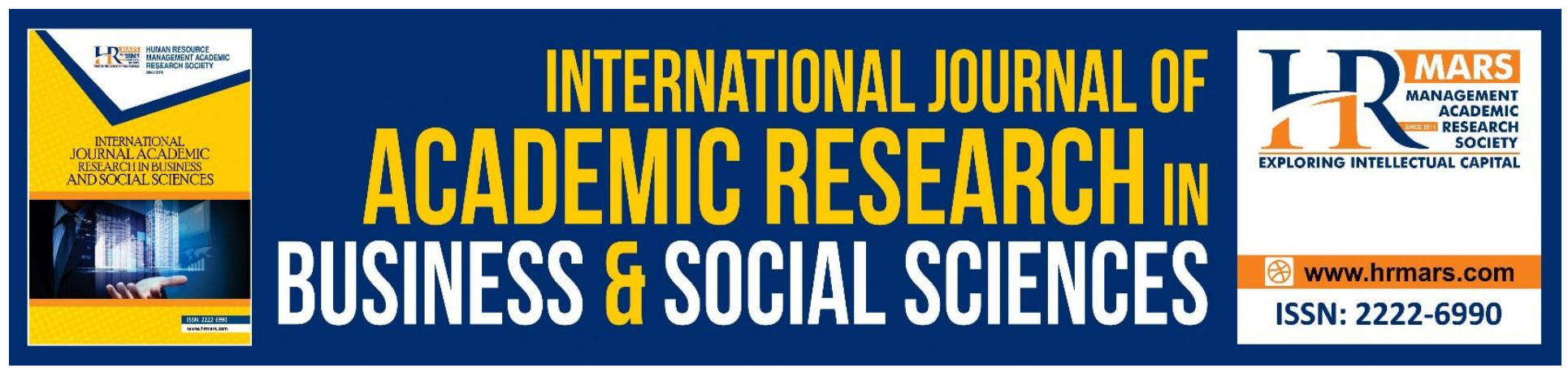

\title{
The Manifestations of a Decent Life for Mankind in the Quran and Sunnah
}

\author{
Sharifah Norshah Bani Syed Bidin, Ahmed S.A. Alqodsi \& Sharifah Noor \\ Shahana Syed Bidin
}

To Link this Article: http://dx.doi.org/10.6007/IJARBSS/v8-i10/4733

DOI: $10.6007 /$ IJARBSS/v8-i10/4733

Received: 15 Sept 2018, Revised: 09 Oct 2018, Accepted: 18 Oct 2018

Published Online: 31 October 2018

In-Text Citation: (Bidin, Alqodsi, \& Bidin, 2018)

To Cite this Article: Bidin, S. N. B. S., Alqodsi, A. S. A., \& Bidin, S. N. S. S. (2018). The Manifestations of a Decent Life for Mankind in the Quran and Sunnah. International Journal of Academic Research in Business and Social Sciences, 8(10), 279-286.

\section{Copyright: (C) 2018 The Author(s)}

Published by Human Resource Management Academic Research Society (www.hrmars.com)

This article is published under the Creative Commons Attribution (CC BY 4.0) license. Anyone may reproduce, distribute, translate and create derivative works of this article (for both commercial and non-commercial purposes), subject to full attribution to the original publication and authors. The full terms of this license may be seen

at: http://creativecommons.org/licences/by/4.0/legalcode

Vol. 8, No. 10, 2018, Pg. 279 - 286

http://hrmars.com/index.php/pages/detail/IJARBSS

JOURNAL HOMEPAGE

Full Terms \& Conditions of access and use can be found at http://hrmars.com/index.php/pages/detail/publication-ethics 


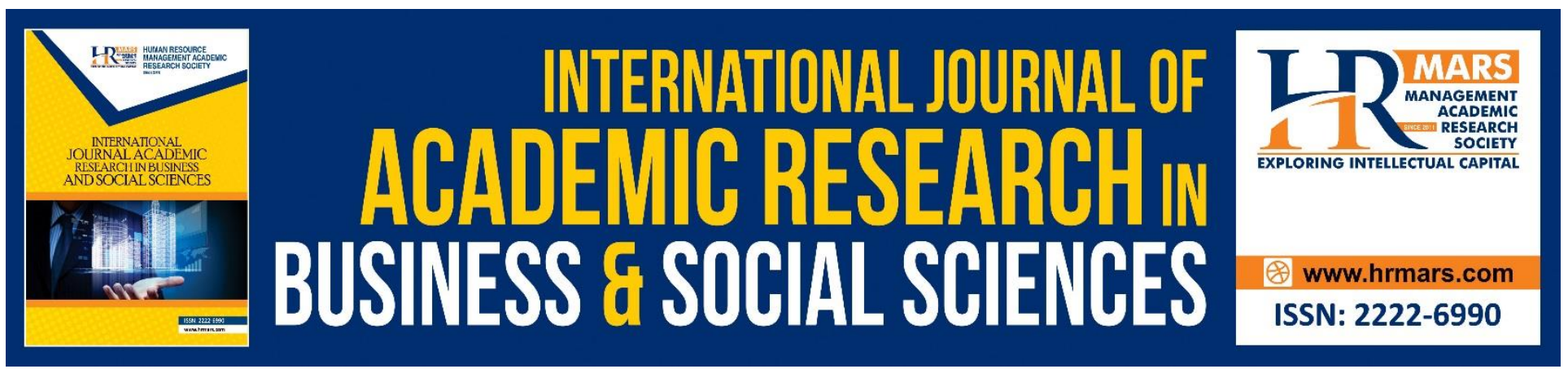

\title{
The Manifestations of a Decent Life for Mankind in the Quran and Sunnah
}

\author{
Sharifah Norshah Bani Syed Bidin ${ }^{1}$, Ahmed S.A. Alqodsi ${ }^{1} \&$ Sharifah \\ Noor Shahana Syed Bidin² \\ ${ }^{1}$ Faculty of Islamic Contemporary Studies, Universiti Sultan Zainal Abidin, \\ Gong Badak Campus, Kuala Terengganu, Terengganu, Malaysia \\ 2 Faculty of Social Science, University College Bestari, 21100 Permaisuri, Setiu, Terengganu, \\ Malaysia.
}

\begin{abstract}
The provisions of the Quran and Sunnah(prophet saying) enshrined in the preservation of human rights, especially in the care of the human right to life. The purpose of this study is to clarify the manifestation of a decent life for the human being from the perspective of Al-Quran and Al-Sunnah. This qualitative research based on the document analysis from the al-Quran and al-Sunnah verses, which are related to the topic. Therefore, the study reached the following results: The provisions of the Qur'an and al-Sunnah guarantee the human being a decent life in four areas; family, living, health, and protection of a criminal.
\end{abstract}

Keywords: Decent Life, Right to Life, Human Right

\section{Introduction}

Life is the trust of God, the Creator of mankind. It is not allowed for mankind to finish his life how and when he wishes, because the decision is due to the real owner; God Almighty. Only He has the capacity and ability to revive and die, as it says in the verse: (It is He who ordains life and death, and to Him, you shall all return to be recompensed" (Yunus: 56). Al-Razi (2001) said that when He was able to revive at the first time, He should be able to revive for the second time.

There have been many manifestations of the human right to human dignity in the Quran and Sunah, to honor the human origin of the emergence and succession; i.e His preference for creatures, and assigned selected human being as messengers, harnessing the universe to Adam (peace be upon him) and his sons, honoring the human mind and his knowledge. Besides that, Allah the Almighty recognizes the rights of children, the elderly and the disabled people and forbade calling by offensive nicknames, and revealed the defects and thought bad, and says: ( $O$ believers! Let not some men among you deride others, who may perhaps be better than they. Nor let some women mock others, who may perhaps be better than they are. Do not defame one another, nor call one another by 
INTERNATIONAL JOURNAL OF ACADEMIC RESEARCH IN BUSINESS AND SOCIAL SCIENCES

Vol. 8, No. 10, Oct. 2018, E-ISSN: 2222-6990 @ 2018 HRMARS

offensive nicknames. (Those who do all these will become evil-doers). An evil thing indeed to be called by a bad name denoting evil-doing after embracing the true faith. And (remember), those who do not repent (from their evil deeds) are indeed wrongdoers" (al-Rum :11).

\section{The Provisions Of Quran And Sunnah In Creating A Decent Life For Mankind}

The Qur'an and Sunnah have provisions that preserve the right to a decent life by virtue of existence. This is reflected in the four areas of human life which are shown below:

\section{First Area: Family}

i. Marriage legislation. Marriage in jurisprudence defined by jurists as: A contract, according to which the pleasure is permissible for a man to get from a woman who does not have an illegal marriage barrier (Abidin, 1992). The al-Quran and al-Sunnah encourage the marriage as it is the way to preserve the human kind. Allah Almighty says And marry among you those who are single (male and female), and the righteous among your slaves, male and female. If they are poor, Allah will enrich them of His Bounty. And Allah is Most Encompassing (in His Blessings and Bounty), Most Knowing. Regarding to this, the Prophet Muhammad (peace and blessings be upon him) had encouraged the marriage provisions in his saying : "0 young men, those among you who can support a wife should marry, for it restrains eyes (from casting evil glances) and preserves one from immorality; but he who cannot afford It should observe fast for it is a means of controlling the sexual desire" (al-Bukhari,1987).

ii. Specific provisions to the child. There are many types of preservation of sharia, which specified to child. First, the legislation of breastfeeding to the child, which aimed to maintain his growth and health, also the obligation of expenses to make sure that the child grows up in a decent life, as well as the nursery to protect him and his education, and forbade killing him even in the war (al-Siba`l,1998). Al-Nawawi(1991) said that Allah has ordered the preservation of the child's right to breastfeed in the Quran verses, saying: "And mothers shall give suck to their children for two whole years, that is if they wish the suckling to be completed" (al-Baqarah: 288). Second, the Prophet (Peace and blessings of Allah be upon him) also concern about expenses of the child as he said in the hadith narrated by Aishah: Hind, the mother of Mu'awiya said to Allah's Messenger (Peace and blessings of Allah be upon him), "Abu Sufyan (her husband) is a miser. Am I allowed to take from his money secretly?" The Prophet (Peace and blessings of Allah be upon him) said to her, "You and your sons may take what is sufficient reasonably and fairly." (al-Bukhari,1987). This means that it is obligatory to make alimony for the child with the money of his father. Al-Bahouti (1983) said: It is enough if he can provide foods, clothes, house and its requirements. If he does not have a portion of money in his house, then he will spend it on the basis of sufficiency and social solidarity (Qutb,n.d).

Third, Shari ah also approved the preservation of the child's right to custody, the mandate to raise him and manage his affairs. Ibn Abidin(1992) said : "It means raising the child for the one who has custody as Allah says : "No mother shall be treated unfairly on account of her child"(al-Baqarah:233) which means "The mother is entitled to take care the child for as long 
as he is a kid". It was reported that a woman said: Messenger of Allah, my womb is a vessel to this son of mine, my breasts, a water-skin for him, and my lap a guard for him, yet his father has divorced me and wants to take him away from me. The Messenger of Allah (苟) said: You have more right to him as long as you do not marry(Daud,n.d).

Fourth, it also preserves the child the right to play and recreation. The Messenger of Allah (peace and blessings of Allah be upon him) used to describe Abdullah and Ubayd Allah, and many of the sons of Abbas. Then he said: He who preceded me has such and such things. He said: "They will come to him and fall on his back and his chest, he then kisses and holds them"(Hanbal,2001). The prophet (peace and blessings of Allah be upon him) also taught children to shoot, and swim, as it is stated that "the child has the right on his father to teach him to write, swim and shoot"(al-Baihaqi,2003).

Fifth, preserve the child's right to mind, which means the formation of his thought with all useful sciences; Islamic law,cultural and modern, as well as intellectual awareness and civilization, to be matured intellectually and scientifically formed, and has the ability to think properly in the future, improve the judgment of things using his experience and benefiting from the experiences of others('Ulwan,1992). Anas ibn Maalik (may Allah be pleased with him) said: "The Messenger of Allah (peace and blessings of Allah be upon him) said: "Seeking knowledge is a duty upon every Muslim"(Majah,n.d) which means that the Prophet (peace be upon him), care about the teaching them writing and reading.

Sixth : Islam also forbade parents deny their relationship with their children. It is narrated from Abu Hurayrah (may Allah be pleased with him) that he heard the Messenger of Allah (peace and blessings of Allah be upon him) say: "Any woman who falsely attributes a man to people to whom he does not belong, has no share from Allah, and Allah will not admit her to His Paradise. Any man who denies his son while looking at him (knowing that he is indeed his son), Allah, the Mighty and Sublime, will cast him away, and disgrace him before the first and the last on the Day of Resurrection"(al-Nasa'l,1991).

Seventh : Save the lineages of the child as Islam abolished the adoption system. Allah says : Call them by (the names of) their fathers: that is juster in the sight of Allah(al-Ahzab:5). Shariah preserves the honor of the child, forbid trafficking and sexual abuse, exploitation of labor, reprisals of the aggressors, and ensuring that the violation is invoked.

\section{Second Area : Life}

i. The provision of housing and clothing. The Quran and Sunnah had urged to take housing and clothing, because they are necessities of a decent life. The human nature need the house and clothes to conceal himself and keep his life from cold, heat and disease. Ashour(2001) in his interpretation of the verse: "It is Allah Who made your habitations homes of rest and quiet for you; and made for you, out of the skins of animals, 
(tents for) dwellings, which ye find so light (and handy) when ye travel and when ye stop (in your travels); and out of their wool, and their soft fibers (between wool and hair), and their hair, rich stuff and articles of convenience (to serve you) for a time (al-Nahl:80), said that this is from the enumeration of the blessings that God inspired to mankind, namely, the grace of thought in the manufacture of protective houses, the muhrim, and the like clothes and furniture, all of which are prepared by Allah for the mind of man and prepared for him the means.

ii. Seeking to earn a halal living.The provisions of the Qur'an and Al-Sunnah had encouraged to seek a livelihood to establish a decent life. Allah says: "It is He Who has made the earth manageable for you, so traverse ye through its tracts and enjoy of the Sustenance which He furnishes: but unto Him is the Resurrection(al-Mulk : 15). The order to traverse through the tracts of the earth in the verse is for the sake of earning a living and establishing a dignified life. Al-Qurtubi(n.d.) said: "The word "manageable" means any easy to settle on it. It was said: He pointed to the ability to plant and plant and cut the eyes and rivers and drilling wells.

\section{Third Area : Health}

i. The consumption of food and beverages. The provisions of the Quran and Sunnah approved eating Halal food and beverages. Allah says : "O ye people! Eat of what is on earth, Lawful and good; and do not follow the footsteps of the evil one, for he is to you an avowed enemy". Ashour(2001) says that the good is meant by the souls to use it. Because Allah does not prevent His slaves from benefiting from a good food and beverages.

ii. The legislation of treatment and prevention. The provisions of Islam on medication and treatment, as in the saying of the Prophet peace be upon him that he said: There is a remedy for every malady, and when the remedy is applied to disease it is cured with the permission of Allah, the Exalted and Glorious. Ibn al-Qayyim(1994) said: The Prophet (peace and blessings of Allah be upon him) said: Umm Al-Mundhir said:"The Messenger of Allah (peace and blessings be upon him) entered upon me, while 'Ali was with him, and we had a cluster of unripe dates hanging." She said: "The Messenger of Allah (peace and blessings be upon him) began eating, and 'Ali ate with him. The Messenger of Allah (peace and blessings be upon him) said to 'Ali: 'Stop, stop, for you are still recovering.' So `Ali sat and the Prophet (peace and blessings be upon him) ate." She said: "I made some chard and barley for them, so the Prophet (peace and blessings be upon him) said: 'O `Ali eat from this, for indeed it will be more suitable for you."(al-Tirmidhi,1975)

iii. Protecting the human from difficulties. These include the provisions of care for the appearance of the body. Al-Qayyim says: such as cutting nails and cutting mustache, 
washing the stitches, pubic shaving, plucking the hair under armpit and using a wooden toothbrush (siwak), and combing hair and using perfume, as the Prophet (peace and blessings be upon him) saying: The inborn characteristics of man are five. Another version says: Five things are of the inborn characteristics of man: circumcision, shaving the pubes, plucking out hair under the armpit, paring the nails and clipping the moustaches(alBukhari,1987). In the care of physical health, such as maintaining the fitness of the body by sports and rest to restore liveliness. al-Qayyim(1994) says: Sleep to calm the souls and regain vitality, and forbade carrying darts in crowded places and markets, a sign of the man to his brother with weapons, and giving uncovered sword, and the abandonment in the shade and passerby.

\section{Fourth Area : Protection Of A Criminal}

i. The prohibition of self-harm or self-abuse. The provisions of the Qur'an and Sunnah have meant a high self-care, which brings the interests and avoid the spoilers. The Qur'an said: "...take not life, which Allah hath made sacred, except by way of justice and law "(alAn`am:151). Al-Qurtubi (n.d.) said: The verse in which it forbids the killing of the forbidden soul is a covenant or a treaty except with the truth that requires killing. The Quran also promised severe torment and immortality in the fire of hell to those who committed to killing himself or others. Allah says: "If a man kills a believer intentionally, his recompense is Hell, to abide therein (For ever): And the wrath and the curse of Allah are upon him, and a dreadful penalty is prepared for him"(al-Nisa':93). The right to life is the first human right, and when it is applied the rest of the rights and when it ends there are no rights.

ii. $\quad$ Fetal care. The right to life is fully recognized for the fetus, and it is not permissible to kill it. Therefore, Islamic law forbade abortion. The fuqaha' have agreed on the prohibition on abortion after the soul is breathed into the fetus. Al-Ghazali(n.d) said that the inviolability of abortions is since it was a sperm, and legalised a certain fine (al-ghurrah) to those who kill the fetus. Besides, Islam also recognized the right to food for fetus, and obliged the husband to provide expenses for his pregnant wife, as well as expenses and housing for the divorced pregnant mother. Allah the Almighty says: "Let the women live (in 'iddat) in the same style as ye live, according to your means: Annoy them not, so as to restrict them. And if they carry (life in their wombs), then spend (your substance) on them until they deliver their burden: and if they suckle your (offspring), give them their recompense: and take mutual counsel together, according to what is just and reasonable. And if ye find yourselves in difficulties, let another woman suckle (the child) on the (father's) behalf"(al-Talaq:6).

The provisions of the Qur'an and Sunnah were dropped from the pregnant woman for the sake of caring for the benefit of the fetus and fearing the consequences of his mother's fatigue during fasting. The prophet (peace and bless be upon him) said: "Allah has remitted half the prayer to a traveller, and fasting to the traveller, the woman who is suckling an infant and the woman who is pregnant"(Daud,n.d.). Even Islam also delayed the punishment on the pregnant 
INTERNATIONAL JOURNAL OF ACADEMIC RESEARCH IN BUSINESS AND SOCIAL SCIENCES

Vol. 8, No. 10, Oct. 2018, E-ISSN: 2222-6990 (C) 2018 HRMARS

woman to put her pregnancy, in order to care for the right of the fetus to life. Rushd(2004) said : "If the pregnant woman is killed deliberately, he is not led from her until she puts her pregnancy".

\section{Conclusion}

The provisions of the Qur'an and the Al-Sunnah preserve human rights, especially in the care of the human right to life. The provisions of the Koran and Al-Sunnah guarantee the human being a decent life in four areas, which are divided to nine details; marriage legislation, eating halal food and drink, taking shelter and clothing, seeking good work and earning money, ordering remedial measures, prevention of self-abuse and taking care of the fetus to live in a dignified life, and protect him from life in distress and hardship.

\section{Acknowledgement}

Special thanks go to the Research Management, Innovation and Commercialization Centre(RMIC), Universiti Sultan Zainal Abidin.

\section{Corresponding Author}

Name : Sharifah Norshah Bani Syed Bidin, Ph.D

Affiliation : Faculty of Islamic Contemporary Studies, Universiti Sultan Zainal Abidin, Kampus Gong Badak, 21300 Kuala Nerus, Terengganu, Malaysia.

Email : sharifahns@unisza.edu.my

\section{References}

Holy Quran

Abidin, I. M. (1992).Rad al-Muhtar 'Ala al-Durr al-Mukhtar.Beirut: Dar al-Fikr.

'Ashour, I. T. (2001). Maqasid al-Syariah al-Islamiyyah. Amman:Dar al-Nafa'is.

Al-Bahouti, M. (1983).Khasshaf al-Qina 'An Matni al-Iqna 'Beirut: 'Alam al-Kutub.

Al-Baihaqi, A. B. (2003).Syu 'ab al-Iman.Riyadh:Maktabah al-Rushd.

Al-Bukhari, M. (1987).al-Jami al-Sahih al-Mukhtasar.Beirut: Dar Ibn Kathir.

Daud, A. S.(n.d.).Sunan Abu Daud. Beirut:Maktabah al-'Asriyyah.

Al-Ghazali, M. (n.d.).Ihya' 'Ulum al-Din. Beirut: Dar al-Fikr.

Hanbal, I. A. (2001).Musnad al-Imam Ahmad bin Hanbal. Beirut: Muassasah al-Risalah.

Majah, I. M.(n.d.).Sunan Ibn Majah.Beirut: Dar al-Fikr.

Al-Nasa'I, A.(1991).Sunan al-Nasa'l al-Kubra. Beirut: Dar al-Kutub al-'Ilmiyyah.

Al-Nawawi, M. Y. (1991).Raudah al-Talibin. Beirut: al-Maktab al-Islami.

Rushd, M. I. (2004).Bidayah al-Mujtahid.Cairo: Dar al-Hadis.

Al-Qayyim, M. I. (1994). Zad al-Ma`ad Fi Huda Khayr al- 'lbad. Beirut: Muassasah al-Risalah.

Al-Qurtubi, M. (n.d.).al-Jami' Li Ahkam al-Quran.Beirut:Dar Ihya' al-Turath al'Arabi.

Qutb, S.(1998).Fi Zilal al-Quran.Cairo: Dar al-Syuruq.

Al-Razi, A. A. (2001).al-Tafsir al-Kabir.Beirut: Dar Ihya' al-Turath al-'Arabi.

Al-Siba'I, M. (1998).Nizam al-Silm wa al-Harb Fi al-Islam. Riyad:Maktabah al-Waraq. 
INTERNATIONAL JOURNAL OF ACADEMIC RESEARCH IN BUSINESS AND SOCIAL SCIENCES Vol. 8, No. 10, Oct. 2018, E-ISSN: 2222-6990 @ 2018 HRMARS

Al-Tirmidhi, M. (1975).Sunan al-Tirmidhi.Cairo:Matba`ah Mustafa al-Babi al-Halabi. 'Ulwan, N. (1992).Tarbiah al-Awlad Fi al-Islam.Cairo:Dar al-Salam. 